\title{
Microhabitat selection and distribution of functional feeding groups of mayfly larvae (Ephemeroptera) in lotic karst habitats
}

\author{
Marina Vilenica ${ }^{1, *}$, Andreja Brigić ${ }^{2}$, Michel Sartori ${ }^{3}$ and Zlatko Mihaljević ${ }^{2}$ \\ ${ }^{1}$ Faculty of Teacher Education, University of Zagreb, Petrinja, Croatia \\ ${ }^{2}$ Faculty of Science, Department of Biology, University of Zagreb, Zagreb, Croatia \\ ${ }^{3}$ Museum of Zoology, Lausanne, Switzerland
}

\begin{abstract}
Research examining mayfly ecology in karst streams and rivers has increased in recent years, though microhabitat preferences remain poorly characterized. We examined mayfly assemblage taxonomy, functional feeding groups and microhabitat preferences in two contrasting lotic Dinaric karst catchments, one pristine and one anthropogenically impacted. At monthly intervals over a one-year period, all major microhabitats (i.e. dominated by boulders, cobbles, sand, silt, mosses, or angiosperms) were sampled at sites spanning springs, upper, middle and lower river reaches, and tufa barriers. In both catchments, mayfly species richness was comparable among microhabitats, while mayfly abundance was highest on mosses and lowest on silt. NMDS ordination did not group assemblages according to microhabitat type, which may reflect the greater influence of physical and chemical water properties. In both catchments and all microhabitats, mayfly assemblages were dominated by grazers/scrapers at upstream sites and by detritivores at downstream sites. Active filter feeders were more abundant in microhabitats with silt substrates and lower current velocities. This study demonstrated that certain mayfly species strongly preferred a specific microhabitat type, reflecting their water current preferences and feeding strategies, while other species shifted between microhabitats, likely in search of food resources and shelter. The results emphasize the importance of habitat heterogeneity in supporting diverse communities in karst rivers.
\end{abstract}

Keywords: Substrate type / water velocity / water depth / mayfly assemblages / feeding groups

Résumé - Choix des microhabitats et répartition des groups trophiques fonctionnels de larves d'éphémères (Ephemeroptera) dans des milieux lotiques et karstiques. Ces dernières années ont vu un accroissement des recherches menées sur l'écologie des éphémères dans les cours d'eau en milieux karstiques, mais leurs préférences à l'échelle du microhabitat restent peu connues. Nous avons étudié la composition taxonomique des éphémères, leurs groupes trophiques fonctionnels et leurs préférences pour les microhabitats dans deux bassins versants du Karst dinarique très différents ; l'un intact, l'autre soumis à des influences anthropogènes. Sur une période d'un an, mensuellement, les principaux microhabitats (par ex. composés principalement de blocs, galets, sable, limon, mousses ou angiospermes) ont été échantillonnés dans des stations couvrant les sources, le cours supérieur, moyen et inférieur des cours d'eau, ainsi que les tufières. Dans les deux bassins, la richesse spécifique en éphémères est comparable entre microhabitats, tandis que l'abondance est maximale dans les mousses et la plus faible dans le limon. Les représentations en NMDS ne regroupent pas les assemblages suivant le type de microhabitats, suggérant ainsi que les paramètres physico-chimiques jouent un rôle plus important. Dans les deux bassins et dans tous les microhabitats la composition en éphémères est dominée par les brouteurs/racleurs dans les sites en amont, et par les détritivores dans les sites en aval. Les filtreurs actifs sont plus abondants dans les microhabitats composés de limon et à faible vitesse de courant. Cette étude confirme que certaines espèces d'éphémères montrent une préférence marquée pour certains types de microhabitats, illustrant ainsi leurs affinités pour certaines vitesses de courant ainsi que leurs préférences alimentaires, tandis que d'autres espèces passent d'un microhabitat à l'autre, probablement à la recherche de nourriture ou d'un abri. Nos résultats mettent

\footnotetext{
*Corresponding author: marina.vilenica@gmail.com
} 
l'accent sur l'importance de l'hétérogénéité des habitats afin de maintenir des communautés diverses dans les cours d'eau karstiques.

Mots clés : Substrat / vitesse du courant / profondeur de l'eau / composition en éphémères / groupes trophiques

\section{Introduction}

Microhabitat preferences of freshwater macroinvertebrates are essential for studying correlations between species and their environment, and in turn for creating an adequate foundation for the conservation of aquatic habitats and their biodiversity (e.g. Urbanič et al., 2005; Sarr et al., 2013; Álvarez-Troncoso et al., 2017). Together with the physical and chemical characteristics of water, microhabitat heterogeneity is another key factor influencing the composition of benthic macroinvertebrate assemblages, with individual species often associated with particular microhabitat types (Corkum et al., 1977; Giller and Malmqvist, 1998; Bauernfeind and Moog, 2000; Subramanian and Sivaramakrishnan, 2005; Arimoro and Muller, 2010; Leitner et al., 2015; Milesi et al., 2016; Sroka et al., 2016). Microhabitat preferences are closely related to substrate type, water velocity and depth, organic matter deposits, food availability, turbulence and hydraulic parameters (Gordon et al., 1992; Lampert and Sommer, 1997; Miliša et al., 2006). The availability of appropriate microhabitats allows macroinvertebrates, including mayfly larvae, to seek refuge from predators and to acquire sufficient food resources (e.g. Corkum et al., 1977; Hawkins, 1985; Dedieu et al., 2015). Both organic substrates (especially macrophytes) and coarse inorganic sediments support high mayfly species richness (Bauernfeind and Moog, 2000; Baptista et al., 2001; Dinakaran and Anbalagan, 2006; Bauernfeind and Soldán, 2012), as they trap more organic matter and provide habitat for periphyton (e. g. Rounick and Winterbourn, 1983; Webster et al., 1987; Dedieu et al., 2015), an important food resource for mayfly larvae.

Based on their feeding strategies and exposure to predation risk, most mayfly species depend on certain microhabitats during their larval stages. Grazers and scrapers prefer microhabitats dominated by macrophytes and/or inorganic sediments coated in diatom-rich biofilms, whereas shredders and gatherers/collectors occur in substrates containing decomposing coarse and fine particulate organic matter (FPOM; e.g. Lamp and Britt, 1981; Buffagni et al., 1995; Bauernfeind and Soldán, 2012). Filter feeders also consume decomposing FPOM either deposited or suspended in the water column. Active filter feeders inhabit fine-grained inorganic substrates associated with lower water velocities, where their gill movements create a water current that actively traps the suspended FPOM. In contrast, passive filter feeders require current velocities to be sufficient to distribute FPOM food particles directly to the larvae (e.g. Bae and McCafferty, 1994, Schmedtje and Colling, 1996; Moog, 2002; Bauernfeind and Soldán, 2012).

The present study was conducted in the Dinaric karst, the largest continuous karst landscape in Europe (Miheve et al., 2010 ) extending over approximately $60,000 \mathrm{~km}^{2}$. Dinaric karst habitats are recognized as a biodiversity hotspot (Bãnãrescu, 2004; Bonacci et al., 2008; Previšić et al., 2009; 2014; Ivković and Plant, 2015), though freshwater habitats in southern
Europe are increasingly impacted by anthropogenic activities including river regulation, resulting in a rapid decline in freshwater biodiversity (Freyhof, 2012; Schwarz, 2012). Habitat alterations have a negative impact on mayfly assemblages leading to the rapid disappearance of many species (e.g. Bauernfeind and Moog, 2000; Brittain and Sartori, 2003; Monaghan et al., 2005). River regulations change hydrological, physical and chemical habitat conditions, and microhabitat composition, which shifts from heterogeneous to homogeneous, becoming dominated by fine-grained substrates (Baxter, 1977; Ward and Stanford, 1979; Graf, 2005). Over the past decade, an increasing number of studies have examined the diverse aquatic insect assemblages of the Dinaric karst (e.g. Previšić et al., 2007; Popijač and Sivec, 2009; Šemnički et al., 2012; Ivković and Plant, 2015), however to date, mayflies have mainly been studied in relation to habitat preferences determined by physical and chemical water characteristics (Vilenica et al., 2014; 2016a; 2016b; 2017), whereas information regarding their microhabitat preferences remains scarce (e.g. Savić et al., 2010). Due to the specificity of karst habitats, several interesting mayfly taxa have been recorded (Vilenica et al., 2016a; 2016b; 2017). Moreover, comprehensive data on microhabitat preferences are so far known for just $58.1 \%$ of European mayfly species (see in Buffagni et al., 2017). Thus, collecting the missing data and comparing microhabitat selection of widely distributed species in karst habitats with literature data (Buffagni et al., 2017) represent an interesting subject of research. Therefore, the main aim of this study was to examine the taxonomic and functional feeding group composition of mayfly assemblages in microhabitats located in different habitats types/river reaches of two contrasting lotic catchments in the Dinaric karst, one pristine and one impacted by anthropogenic activities.

\section{Methods}

\subsection{Study area}

The study was conducted in two catchments spanning two biogeographical regions in the Dinaric Western Balkan region of Croatia: Plitvice Lakes National Park in the Alpine region $\left(44^{\circ} 51^{\prime} \mathrm{N}, 15^{\circ} 34^{\prime} \mathrm{E}\right)$, and the Cetina River and its tributary, the Ruda River, in the Mediterranean region $\left(43^{\circ} 26^{\prime} \mathrm{N}, 16^{\circ} 41^{\prime} \mathrm{E}\right.$; Fig. 1) (EEA, 2008). The Plitvice Lakes catchment has a temperate humid climate with warm summer, while the Cetina River catchment has a temperate humid climate with hot summer (Köppen climate classification; Šegota and Filipčić (2003)).

The Plitvice barrage lake system is located in the area of Plitvice Lakes National Park, designated as a UNESCO natural World Heritage Site in 1979 (IUCN, 1979). The Plitvice Lakes catchment consists of 16 oligotrophic and oligo-mesotrophic, dimictic, fluvial lakes interconnected by lotic tufa barriers (second stream order; Stahler, 1952) (Fig. 1a). Two small 


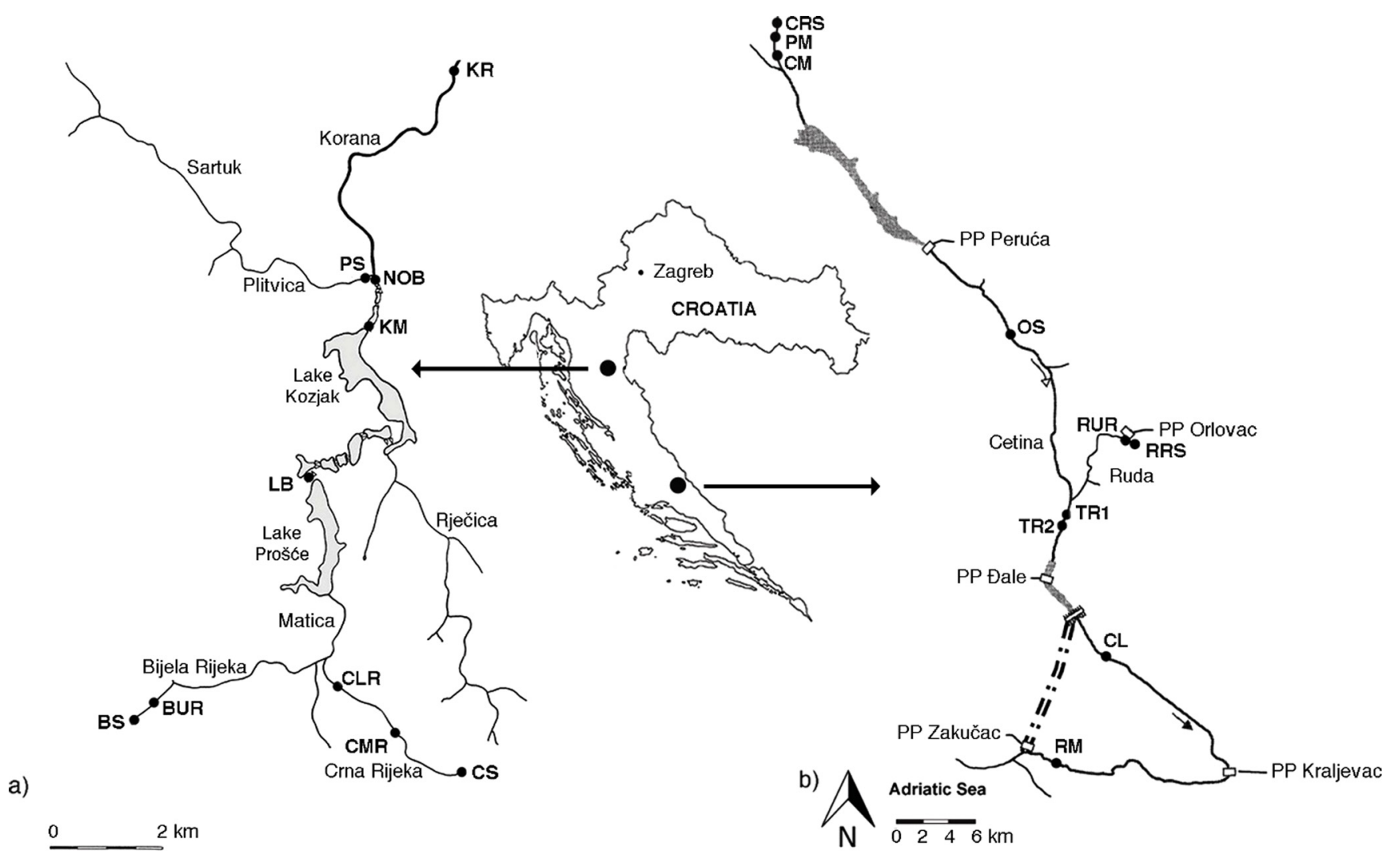

Fig. 1. Location of the study area in Croatia with study sites of microhabitat sampling. a) Plitvice Lakes National Park: Upper lotic habitats: BS - Bijela Rijeka River spring, BUR - Bijela Rijeka River upper reaches, CS - Crna Rijeka River spring, CMR - Crna Rijeka River middle reaches, CLR - Crna Rijeka River lower reaches; Tufa barriers: KM - Tufa barrier Kozjak-Milanovac, LB - Tufa barrier Labudovac, NOB Tufa barrier Novakovića Brod; Lower lotic habitats: KR - Korana River, PS - Plitvica Stream. b) Cetina and Ruda Rivers: Springs: CRS Cetina River spring (Glavaš), RRS - Ruda River spring; Upper reaches: PM - Preočki Most, CM - Crveni Most, RUR - Ruda River upper reaches; Middle reaches: OS - Obrovac Sinjski, TR1 - Trilj1, TR- Trilj2; Lower reaches: CL - Čikotina Lađa, RM - Radmanove Mlinice. PP - power plant; (dashed line shows subterranean water channel). Figures are modified from Vilenica et al. (2014) and Vilenica et al. (2016b).

mountainous rivers (first stream order) upstream of the barrage lake system, Bijela Rijeka River and Crna Rijeka River, join to form the Matica River (second stream order), the main surfacewater supplier of the lakes (Stilinović and Božičević, 1998). Mean annual air temperature during the study period (year 2007) was $11.4^{\circ} \mathrm{C}$, with a mean minimum temperature of $-0.5^{\circ} \mathrm{C}$ in December, and a mean maximum of $21.1^{\circ} \mathrm{C}$ in July. Annual rainfall during the study period was $1661 \mathrm{~mm}$, with a minimum of $12 \mathrm{~mm}$ in April and maximum of $228 \mathrm{~mm}$ in October (Meteorological and Hydrological Institute of Croatia; www.meteo.hr).

The Cetina River (first and second stream order) stretches for $105 \mathrm{~km}$ from its spring source to its mouth at the Adriatic Sea (Fig. 1b). It is characterized by the inflow of numerous lateral springs (UNEP/MAP/PAP, 2000) along its course, including the Ruda River encompassed within this study. Mean annual air temperature during the study period (year 2004) was $12.9^{\circ} \mathrm{C}$, with a mean minimum temperature of $2.5^{\circ} \mathrm{C}$ in December, and a mean maximum of $23.2^{\circ} \mathrm{C}$ in July. Annual rainfall during the study period was $1347 \mathrm{~mm}$, with a minimum of $8 \mathrm{~mm}$ in July and a maximum of $214 \mathrm{~mm}$ in April (Meteorological and Hydrological Institute of Croatia; www.meteo.hr). The Cetina River catchment is impacted by anthropogenic pressures including five hydropower plants, the inflow of untreated domestic and agricultural effluents, and groundwater abstraction for public water supply (UNEP/ MAP/PAP, 2000; see also Vilenica et al., 2016b).

\subsection{Sampling strategy}

Microhabitats were sampled at ten study sites in each catchment. In the Plitvice Lakes catchment, sites encompassed the following habitat types: i) springs (BS, CS) and downstream sections (BUR, CUR, CLR) of small mountainous rivers (first stream order); Bijela Rijeka River and Crna Rijeka River located upstream of the barrage lake system (upper lotic habitats); ii) tufa barriers (LB, KM, NOB) (second stream order); and iii) the canyon-type mountainous Plitvica Stream (PS) (first stream order) and the mid-altitude large Korana River (KR) (second stream order), located downstream of the barrage lake system (lower lotic habitats) (Fig. 1a; for details, see Vilenica et al., 2017). In the Cetina River catchment, the ten study sites represented the following habitat types: i) springs (CRS, RS); ii) upper reaches (PM, CM, RUR) (first stream order); iii) middle reaches (OS, TR1, TR2); and iv) lower reaches (CL, RM; Fig. 1b) (second stream order).

Sampling in the Plitvice Lakes catchment was conducted monthly from February 2007 to February 2008, and in the 


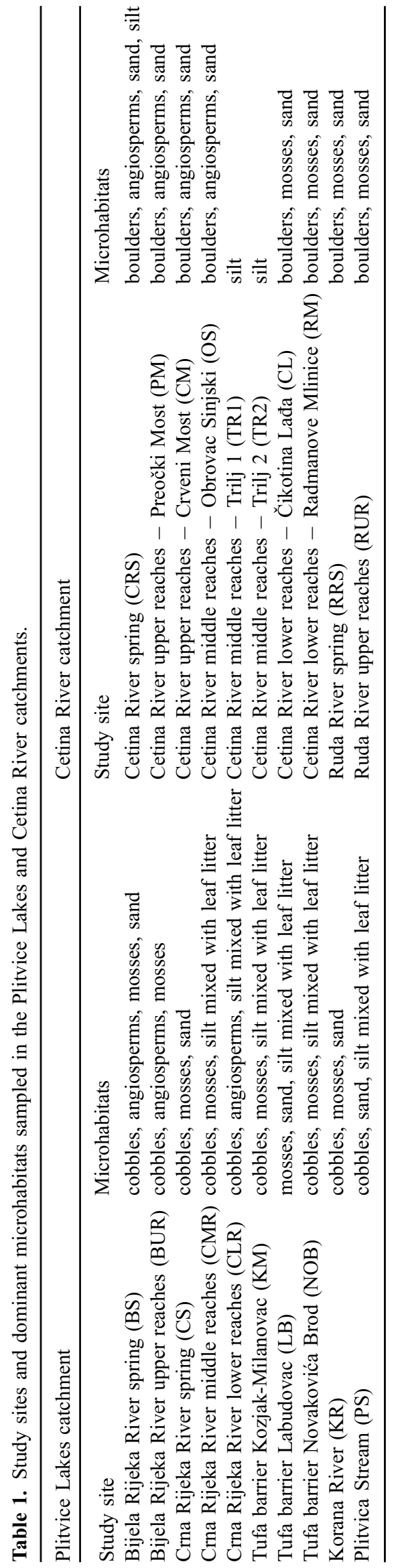

Cetina River catchment between August 2004 and August 2005 to capture taxa with diverse and contrasting life cycles (Vilenica et al., 2016c).

At each site and in each month, triplicate samples were taken in all microhabitat types accounting for $\geq 5 \%$ of the channel area. In the Plitvice Lakes catchment, microhabitat types comprised those dominated by submerged native angiosperms, mosses, cobbles, sand, and silt mixed with leaf litter; while in the Cetina River, catchment microhabitat types consisted of those dominated by submerged native angiosperms, mosses, boulders, sand, and silt (Tab. 1).

\subsection{Mayfly sampling and identification}

In association with collection of each individual sample, inorganic substrate categories were defined based on Wentworth (1922). Water velocity was measured using a P-670-M velocimeter (Dostmann electronic) and depth was measured using a depth-meter.

At most sampling points, macroinvertebrates including mayfly larvae were collected using Surber samplers (mesh size: $0.5 \mathrm{~mm}$; surface area in the Cetina River catchment $33 \times 33 \mathrm{~cm}$; surface area in the Plitvice Lakes catchment $14 \times 14 \mathrm{~cm}$ on mosses [due to very high macroinvertebrate abundance] and $25 \times 25 \mathrm{~cm}$ in other microhabitats). At sites in the lower reaches of the Crna Rijeka River (CLR) in the Plitvice Lakes catchment and two sites in the Cetina River catchment (TR1, TR2), deep water prevented Surber sampling and macroinvertebrates were collected over a comparable surface area using a D-frame hand net (mesh size $0.5 \mathrm{~mm}$ ). Samples were preserved in $80 \%$ ethanol.

Mayflies were identified to the lowest possible taxonomic level (species, genus, or occasionally family, depending on the instar) using resources listed in Vilenica et al. (2015). All voucher specimens were deposited at the Department of Biology, Faculty of Science, University of Zagreb, Croatia. Each taxon was enumerated and abundance expressed as individuals $\mathrm{m}^{-2}$ to allow comparison of different-sized samples.

\subsection{Data analysis}

One-way ANOVA tests with the unequal N HSD post hoc test were used to identify differences in water velocity and depth between microhabitat types.

The studied catchments differ in terms of key environmental influences on mayfly assemblages (i.e. habitat complexity, habitat diversity, and water physical and chemical properties) and therefore support contrasting assemblages (Bauernfeind and Soldán, 2012). All analyses were therefore conducted separately for samples collected from the Plitvice Lakes and Cetina River catchments, to allow comparison of patterns based on samples containing distinct but overlapping mayfly assemblages. Only species data were included in the analyses.

Hierarchical cluster analysis (HCA) and non-metric multidimensional scaling (NMDS) ordination based on a Bray-Curtis similarity matrix were used to examine variability in mayfly assemblage composition among microhabitats (Ramette, 2007). HCA results were superimposed on the 
Plitvice Lakes catchment

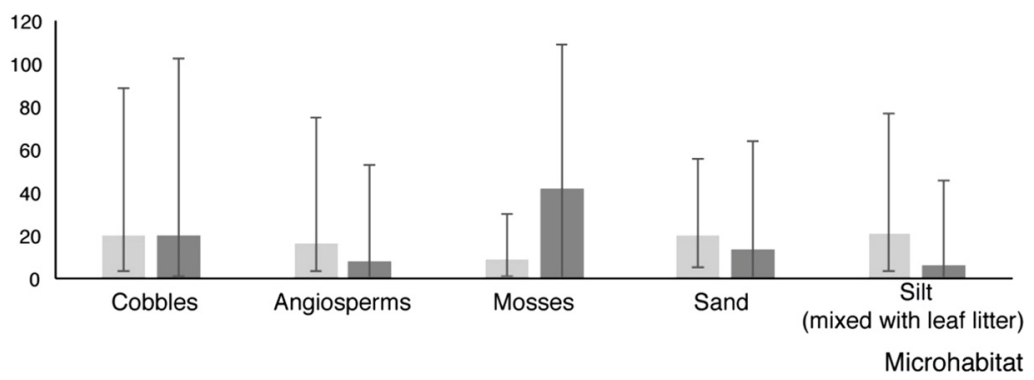

a)

Water depth $(\mathrm{cm})=$ Water velocity $\left(\mathrm{cm} \mathrm{s}^{-1}\right)$

Cetina River catchment

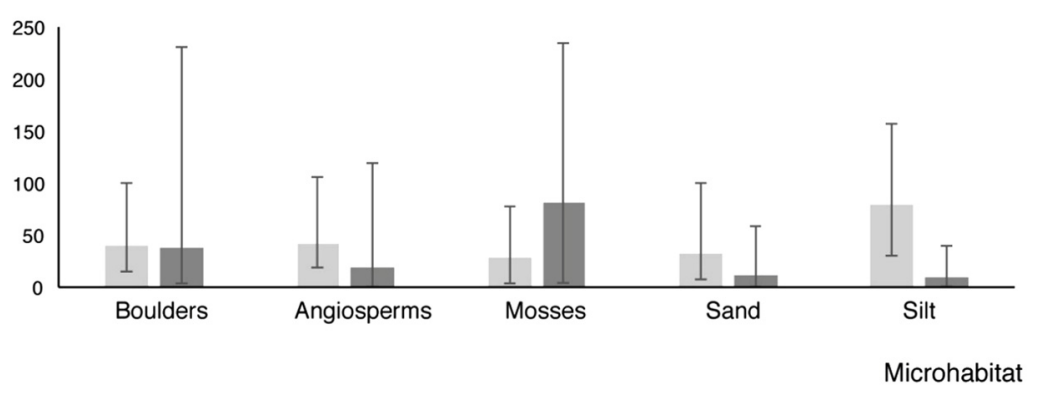

b) $\quad$ Water depth $(\mathrm{cm}) \varpi$ Water velocity $\left(\mathrm{cm} \mathrm{s}^{-1}\right)$

Fig. 2. Water depth and velocity (mean \pm SD) in different microhabitat types measured over a one-year period in a) the Plitvice Lakes catchment and b) the Cetina River catchment.

NMDS ordination, to determine similarity percentage between microhabitats located in different study sites. Data were logtransformed prior to analysis.

The functional feeding group composition of mayfly assemblages in different microhabitats was classified using Buffagni et al. (2009), Buffagni et al. (2017) and Bauernfeind and Soldán (2012). The functional feeding group of each individual species is presented as a proportion of the assemblage. Since most taxa do not exclusively feed on a single food resource, the assignment of taxa to a particular category is based on the ten-point assignment scale (SchmidtKloiber and Hering, 2015). Using the given points and percentage of each species within the assemblage, the functional feeding group composition of mayfly assemblages at each microhabitat type was calculated.

To determine differences among microhabitats in species richness, total abundance, the abundance of individual species and feeding group proportions, non-parametric Kruskal-Wallis $\mathrm{H}$ tests were used, followed by multiple-comparison post hoc tests.

Indicator Value Analysis (IndVal; Dufrêne and Legendre, 1997) was used to identify species indicative of a microhabitat type. This analysis is based on the specificity and fidelity measured for each taxon in an assemblage, with indicator values ranging from 0 to $100 \%$ and reaching a maximum when all individuals of a taxon are recorded in only a single microhabitat type (high specificity) and when the taxon is present in all samples of that microhabitat type (high fidelity). Thus, species indicative of a particular microhabitat, have high and significant percentage IndVals $(>55 \%)$ and were considered symmetrical indicators. The indicator values were tested for statistical significance using Monte Carlo tests with 4,999 permutations.

Spearman's rank correlation coefficients were used to assess the correlation of species richness, total abundance, and the abundance of individual species with water velocity and water depth.

NMDS analysis was conducted in Primer 6 (Clarke and Gorley, 2006). One-way ANOVA, Kruskal-Wallis H test and Spearman's rank correlation coefficient were calculated in Statistica 13.0 (Dell Inc., 2016), and IndVal was performed using PC-ORD version 5.0 (McCune and Mefford, 2006).

\section{Results}

\subsection{Water depth and water velocity analysis}

Water depth (one-way ANOVA, $F=5.72, d f=4.27$, $p<0.01)$ and velocity $(F=15.36, d f=4.27, p<0.001)$ differed among microhabitats in the Plitvice Lakes catchment. Depth was lower in microhabitats with mosses compared to those with cobbles, sand, and silt mixed with leaf litter (unequal $\mathrm{N}$ HDS post hoc tests, $p<0.001$; Fig. 2a). Velocity was higher in mosses compared with all other microhabitats $(p<0.01)$. Additionally, velocity was also higher in the cobbles microhabitat compared to silt mixed with leaf litter $(p<0.05$; Fig. 2a).

In the Cetina River catchment, depth $(F=11.72, d f=4.21$, $p<0.001)$ and velocity $(F=8.40, d f=4.21, p<0.001)$ also differed among microhabitats. Depth was higher in the silt microhabitat compared to sand, mosses $(p<0.001)$, boulders $(p<0.01)$ and angiosperms $(p<0.05$; Fig. $2 b)$. Water velocity 
was higher in the mosses microhabitat compared to sand, silt $(p<0.01)$ and angiosperms $(p<0.05)$, and was higher in the boulders microhabitat compared to silt ( $p<0.05$; Fig. $2 b)$.

\subsection{Mayfly assemblages}

A total of 14 mayfly species (Tab. 2) were recorded in the Plitvice Lakes catchment. NMDS ordination (Fig. 3a) showed that mayfly assemblages generally did not group based on microhabitat type. Species richness was comparable among microhabitats (Kruskal-Wallis $\mathrm{H}$ test, multiple comparisons post hoc test, $\mathrm{H}[4, N=31]=6.25, p>0.05)$, ranging between a total of 11 species each in the microhabitats with angiosperms, sand, and silt mixed with leaf litter, to eight species in moss microhabitats. Abundance was highest in mosses and lowest in silt mixed with leaf litter $(\mathrm{H}[4, N=31]=10.87, p<0.05$; Tab. 2 ). Mayfly abundance was negatively correlated with water depth (Spearman's rank correlation, $R=-0.17, p<0.001$ ) and positively with velocity $(R=0.12, p<0.05)$.

In the Cetina River catchment, a total of 21 mayfly species (Tab. 2) were recorded. Assemblages generally did not group based on microhabitat type in the NMDS ordination space (Fig. 3b). Species richness $(\mathrm{H}[4, N=25]=0.17, p>0.05)$ and abundance $(\mathrm{H}[4, N=25]=8.15, p>0.05)$ were comparable among microhabitats, with a total of 19 species recorded on sand, 17 on boulders, 16 on mosses, 11 on angiosperms and eight on silt. Silt microhabitats had the lowest abundance, while mosses had the highest, though these differences were not statistically significant. Mayfly species richness (Spearman's rank correlation, $R=-0.11, p<0.05)$ and abundance $(R=-0.23, p<0.001)$ were negatively correlated with water depth and positively with water velocity $(S, R=0.32$, $p<0.001 ; N, R=0.41, p<0.001)$.

\subsection{Microhabitat preferences of mayfly species}

In both catchments, a high number of species were collected from all microhabitats within the catchment (Tab. 2). Yet, some species showed a significant preference for a particular microhabitat type.

In the Plitvice Lakes catchment, Baetis cf. nubecularis was indicative of moss microhabitats (IndVal $=72.50, p<0.01$ ), with no significant indicators identified for any other microhabitat. Additionally, $B$. cf. nubecularis was more abundant in mosses compared to silt mixed with leaf litter (Kruskal-Wallis and multiple comparisons post hoc tests; $\mathrm{H}$ [4, $N=22]=16.28, p<0.01)$ and sand $(p<0.05$; Tab. 2). Baetis rhodani was more abundant in mosses compared to silt mixed with leaf litter $(\mathrm{H}[4, N=28]=14.53, p<0.01)$, Ephemera danica was most abundant in sand and absent from mosses $(\mathrm{H}$ [4, N=21] =13.22, $p<0.05$; Tab. 2), and Rhithrogena braaschi was most abundant in cobbles and absent from silt mixed with leaf litter $(\mathrm{H}[4, N=19]=10.19, p<0.05$; Tab. 2).

Serratella ignita (Spearman's rank correlation, $R=-0.18$, $p<0.01), B$. cf. nubecularis $(R=-0.18, p<0.01)$ and $B$. rhodani $(R=-0.12, p<0.05)$ were negatively correlated with water depth, whereas $C$. luteolum $(R=-0.22, p<0.01)$ and $E$. danica $(R=-0.20, p<0.01)$ were positively correlated. Baetis cf. nubecularis $(R=0.36, p<0.001), B$. rhodani $(R=0.14$, $p<0.05)$ and $R h$. braaschi $(R=0.16, p<0.05)$ were positively correlated with water velocity, while $C$. luteolum $(R=-0.49$, $p<0.001)$, E. danica $(R=-0.39, p<0.001)$, Habrophlebia lauta $(R=-0.40, p<0.001)$ and Paraleptophlebia submarginata $(R=-0.19, p<0.01)$ were negatively correlated.

In the Cetina River catchment, Baetis lutheri was indicative of moss microhabitats (IndVal=87.00, $p<0.001$; Kruskal-Wallis and multiple comparisons post hoc tests; $\mathrm{H}[2$, $N=12]=9.99, p<0.01$; Tab. 2) and Rh. braaschi of boulder microhabitats $($ IndVal $=60.3, p<0.01)$. Other mayfly species had low IndVal values.

Baetis rhodani (Spearman's rank correlation, $R=-0.12$, $p<0.05$ ) was negatively correlated with water depth, while Ecdyonurus macani $(R=0.18, \quad p<0.05)$ and $S$. ignita $(R=0.14, p<0.05)$ were positively correlated. Baetis lutheri $(R=0.44, \quad p<0.001), \quad$ Ecdyonurus venosus $(R=0.26$, $p=0.001)$, Epeorus assimilis $(R=0.32, p<0.001), \quad R h$. braaschi $(R=0.32, p<0.001)$, Baetis melanonyx $(R=0.28$, $p<0.05)$ and Ephemerella mucronata $(R=0.41, p<0.05)$ were positively correlated with water velocity while the abundances of $E$. danica $(R=-0.38, p<0.001)$ and Ephemera lineata $(R=-0.18, p<0.01)$ were negatively correlated.

\subsection{Functional feeding groups}

In the Plitvice Lakes catchment, microhabitats with cobbles had a higher proportion of grazers compared to microhabitats with silt mixed with leaf litter (Kruskal-Wallis $\mathrm{H}$ test, multiple comparisons post hoc test; $\mathrm{H}[4, N=31]=11.34, p<0.05)$ and a lower proportion of gatherers/collectors compared to microhabitats with mosses $(\mathrm{H}[4, N=31]=14.49, p<0.01)$. Additionally, microhabitats with silt mixed with leaf litter had a higher proportion of active filter feeders compared to microhabitats with mosses $(\mathrm{H}[4, N=31]=12.32, p<0.05)$. Furthermore, all microhabitats in the upper lotic habitats were dominated by grazers/scrapers followed by gatherers/collectors. In the lower reaches of the Crna Rijeka River, active filter feeders also occurred in microhabitats on silt mixed with leaf litter. Microhabitats located at tufa barriers and lower lotic habitats had a higher proportion of gatherers/collectors while active filter feeders were most numerous in microhabitats at tufa barriers. In the latter two habitat types, mosses had the highest proportion of gatherer/collectors, sand and silt mixed with leaf litter were dominated by gatherers/collectors and active filter feeders, while on the cobbles, all three feeding groups occurred (Fig. 4).

Feeding group proportions were comparable among microhabitats in the Cetina River catchment $(\mathrm{H}[4, N=25]=4.61$, $p>0.05)$. However, mayfly assemblages in microhabitats located in springs and upper reaches were dominated by grazers/scrapers followed by gatherers/collectors. All microhabitats in the middle and lower reaches had the highest proportion of gatherers/ collectors. Active filter feeders appeared in the middle reaches and were distributed in all microhabitats situated downstream, with the highest proportion on sand (Fig. 5).

\section{Discussion}

Although the two studied catchments differed in the extent of anthropogenic pressure, mayfly assemblages were relatively diverse at both (Vilenica et al., 2016a; 2016b; 2017), while some similarities were seen in microhabitat selection. In both 
M. Vilenica et al.: Knowl. Manag. Aquat. Ecosyst. 2018, 419, 17

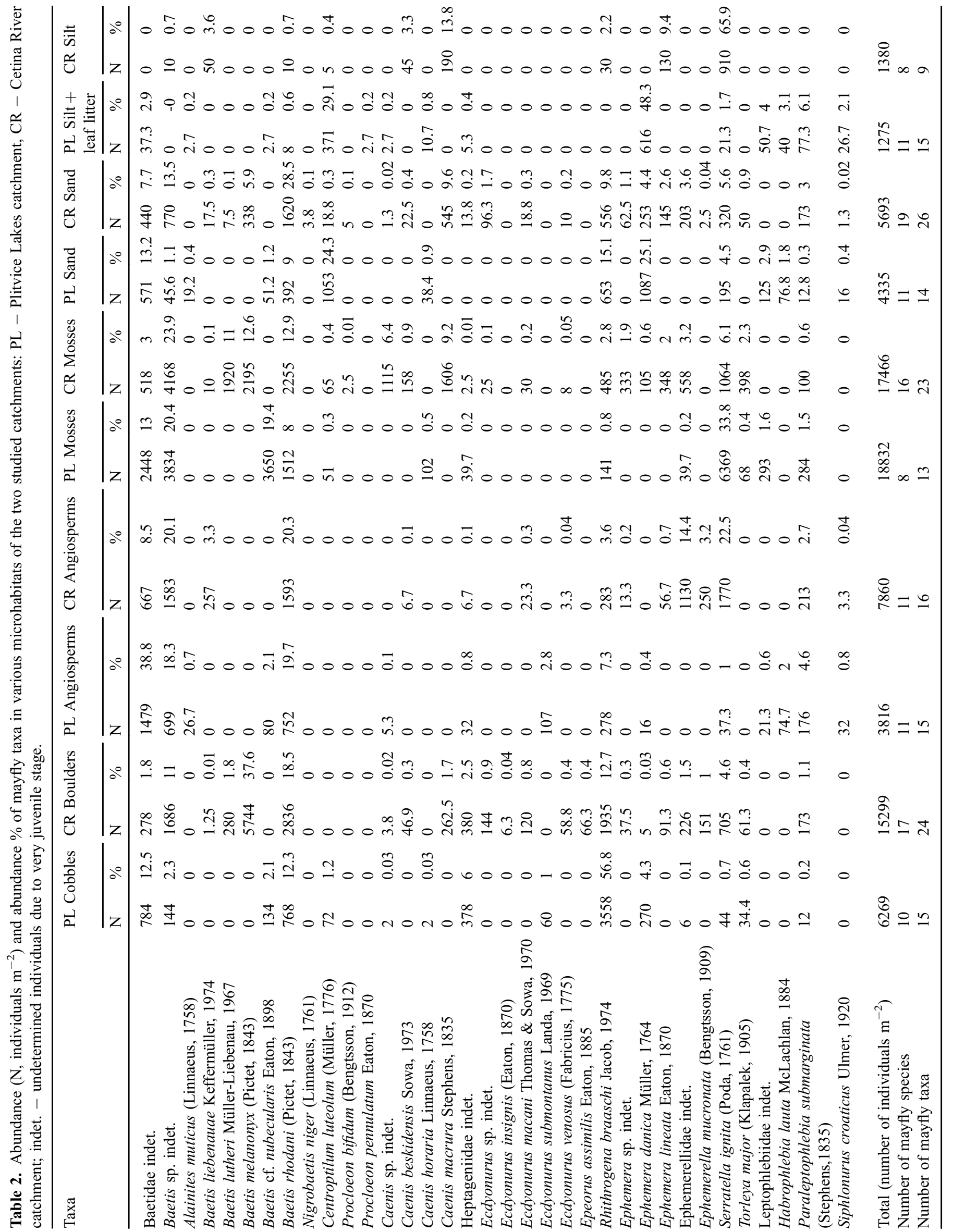




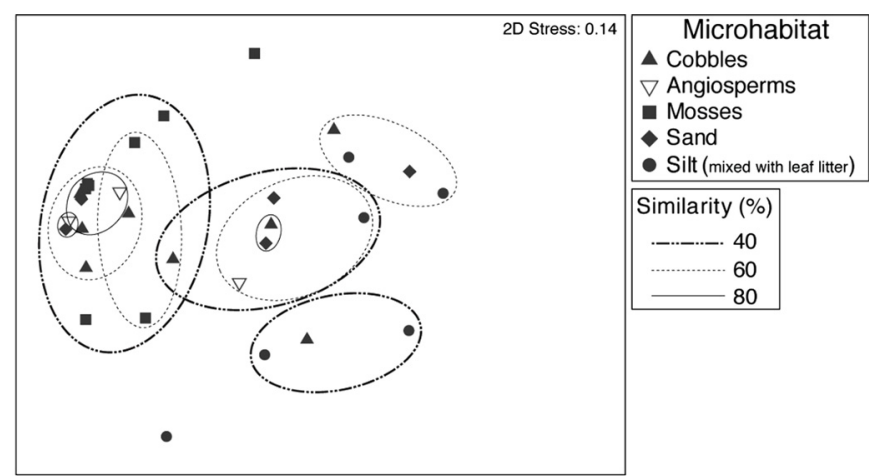

a)

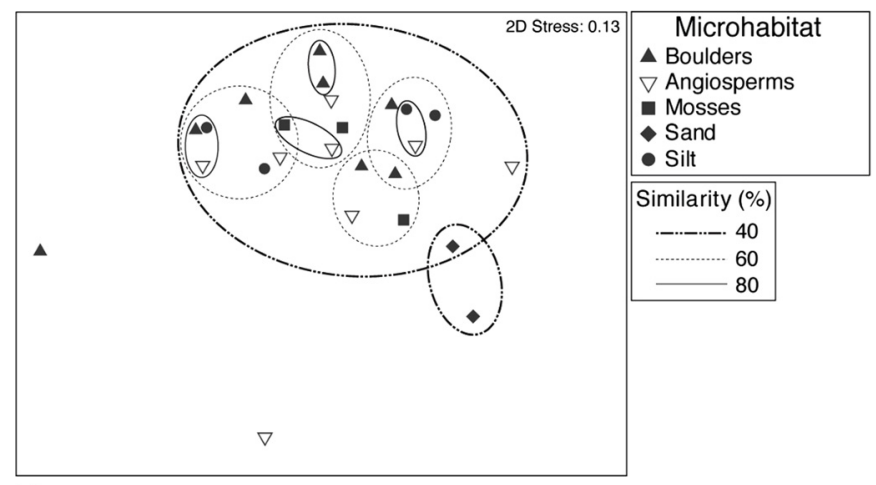

b)

Fig. 3. Non-metric multidimensional scaling (NMDS) ordination of mayfly assemblages based on Bray-Curtis similarity coefficient (group average linking) and their log transformed abundances based on microhabitat type in: a) Plitvice Lakes catchment and b) Cetina River catchment. Results are shown pooled per sampling point (microhabitat).

catchments, species richness was comparable among microhabitats, which could be related to flow conditions, oxygen and nutrient availability (e.g. Ciborowski and Clifford, 1983; Collier, 1994). These results are also a consequence of the varying compositions of mayfly assemblages, with different proportions of species exhibiting a range of substrate preferences, i.e. from species found on a wide range of substrates (e.g. S. ignita, B. rhodani) to microhabitat specialists (e.g. E. assimilis, Rh. braaschi, E. danica) (Buffagni et al., 2009; 2017). Additionally, previous studies showed that many mayfly species shift between microhabitats during their life cycles in search of adequate food resources and shelter (Ciborowski and Clifford, 1983; Holomuzki and Messier, 1993; Collier, 1994; Bauernfeind and Soldán, 2012), and this merits further detailed inspection in this study area.

Water velocity, depending on water discharge, is of exceptional importance in microhabitat selection, as besides directly influencing benthic invertebrates, it also controls the distribution of substrate and food, and influences oxygen concentration (Ciborowski, 1983). Thus, the highest mayfly abundances in both studied catchments were recorded at microhabitats such as mosses or coarse sized sediment (i.e. cobbles, boulders) associated with higher water velocity, smaller depth and higher amounts of available food resources (Plenković-Moraj et al., 2002; Miliša et al., 2006; Špoljar et al., 2007). The fine substrate is generally known to support relatively poor macroinvertebrate species richness (Minshall, 1984), which was confirmed for mayflies in the regulated catchment of the Cetina River. However, this is most likely a consequence of the generally poor environmental conditions related to the accumulation of muddy sediment in the Cetina River (see Vilenica et al., 2016b). On the contrary, though in markedly lower numbers, a large part of the recorded species in the pristine catchment of the Plitvice Lakes inhabited silt mixed with leaf litter, which could have provided more substantial food resources in the otherwise oligotrophic water quality (Špoljar et al., 2007; Gligora Udovič et al., 2017).

The NMDS analyses indicated the lack of a specific preference for microhabitat type among the mayfly assemblages. Additionally, the majority of species showed no exclusive preference for a specific substrate type. Vilenica et al. $(2016 \mathrm{~b} ; 2017)$ showed that mayfly assemblages in the Plitvice Lakes catchment primarily grouped according to the habitat type, and according to the particular river reaches in the Cetina River catchment. This could indicate higher mayfly preference for the specific physical and chemical water properties important in defining river sections and/or habitat types, rather than for a particular substrate.

Nevertheless, some mayfly species showed a distinct preference for a specific microhabitat. For instance, in the Cetina River catchment, $B$. lutheri preferred microhabitats with mosses, which is not in agreement with its typical preferences, as the species is listed as a mesolithal habitat specialist, occasionally recorded from akal and macrophytes (Buffagni and Desio, 1994; Buffagni et al., 2009; 2017). In the Cetina River catchment, however, microhabitats with mosses had the highest water velocities, which is possibly the reason for the preference shown by this rheophilous species (see also in Vilenica et al., 2016a). Though the eurytopic and rheophilous $B$. rhodani inhabited all available microhabitats in both catchments, it showed a preference for microhabitats with higher water velocity (Buffagni et al., 2009; 2017). In addition, it showed a significant preference for substrate type in the Plitvice Lakes catchment, where it favoured microhabitats on mosses, and avoided microhabitats on silt mixed with leaf litter. Moreover, as the highest abundance of young larval instars of Baetidae was also recorded on mosses, this was likely the most suitable substrate providing food and shelter for younger instars. In accordance with literature data (Buffagni et al., 2009; 2017), statistically supported specific microhabitat dominance was also seen in E. danica in both catchments and B. cf. nubecularis in the Plitvice Lakes catchment. The rheo- to limnophilous and predominantly psammal species $E$. danica preferred microhabitats on sandy substrates associated with slower water current (Buffagni et al., 2009; Bauernfeind and Soldán, 2012; Buffagni et al., 2017), while $B$. cf. nubecularis favoured microhabitats on mosses associated with the fastest current. Though the taxonomical status of the latter species is not yet resolved, the larvae of the Baetis alpinus group typically prefer lotic habitats exposed to fast currents, and tend to inhabit stony substrates from crenal to metarhithral sections of fast flowing streams (Bauernfeind and Soldán, 2012). This could indicate a species preference for higher water velocity rather than for the mossy substrate, since these were the sites of significantly higher water velocity. In both catchments, the rheophilous $R h$. braaschi preferred microhabitats on coarse sediment (cobbles, 

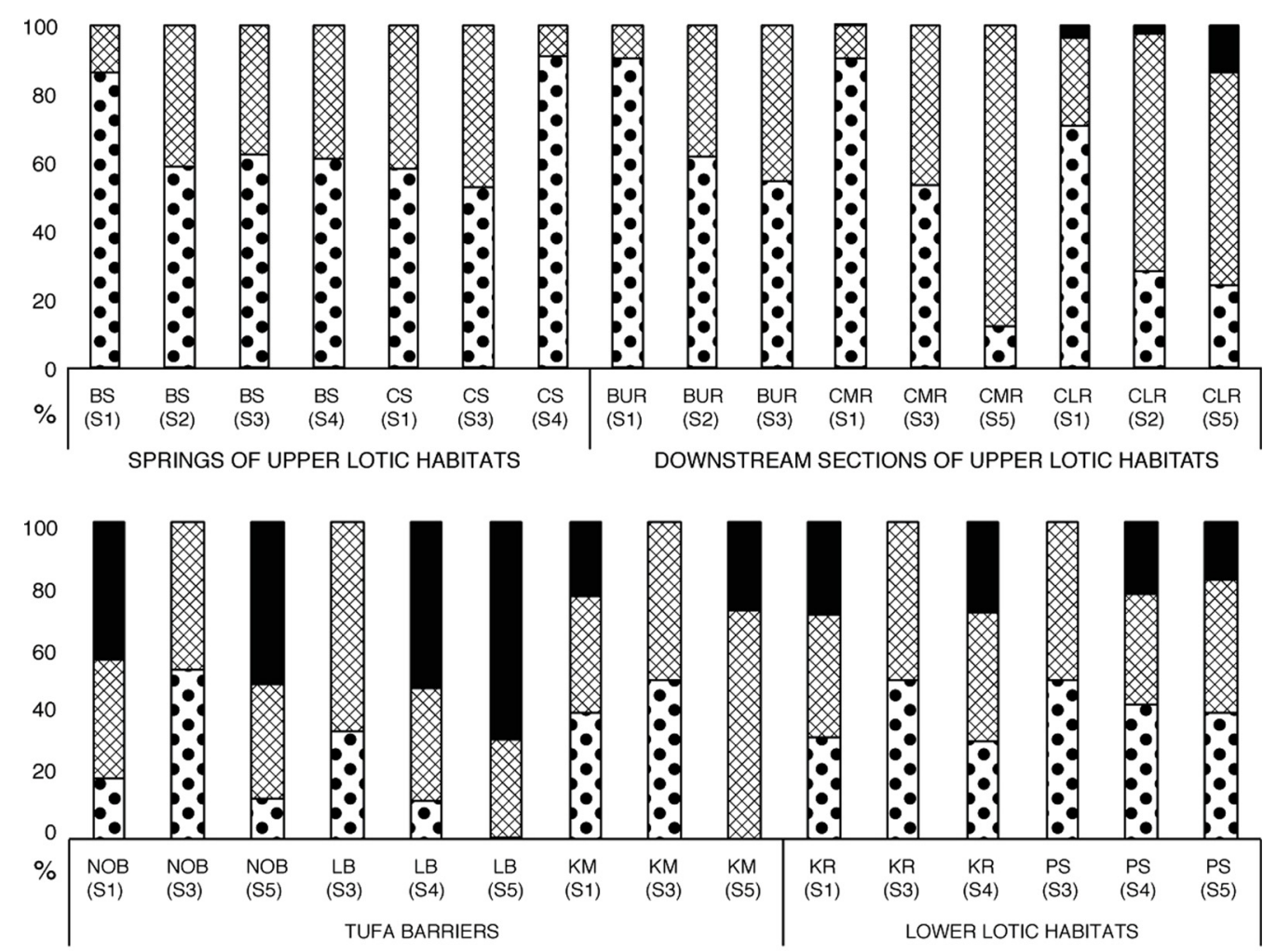

$\because$ Grazer/scraper Gatherer/collector $\square$ Active filter feeder

Fig. 4. Percentage abundance of diverse functional feeding groups of mayfly assemblages and their distribution in various habitats and microhabitats in the Plitvice Lakes catchment. Legend: S1 - cobbles; S2 - angiosperms; S3 - mosses; S4 - sand; S5 - silt mixed with leaf litter. For abbreviations of study site names see Fig. 1.

boulders) and faster water current, which is in accordance with its typical microhabitat selection (Buffagni et al., 2009; 2017).

Finally, though several species did not show an exclusive preference for a specific substrate type, they were found to favour certain microhabitats. Thus, significant preferences for microhabitats with higher current and lower water depth were shown for the rheophilous B. melanonyx, rheo- to limnophilous $E$. venosus and $E$. mucronata, and the rheobiont $E$. assimilis in the Cetina River catchment (Buffagni et al., 2009; Bauernfeind and Soldán, 2012; Buffagni et al., 2017). On the other hand, several species favoured microhabitats with lower water velocity and greater water depth, such as the limnophilous $C$. luteolum, limno- to rheophilous $H$. lauta, rheo- to limnophilous . submarginata in the Plitvice Lakes catchment, as well as the limno- to rheophilous E. lineata in the Cetina River catchment (Buffagni et al., 2009; Bauernfeind and Soldán, 2012; Buffagni et al., 2017). Interestingly, in the pristine Plitvice Lakes catchment, S. ignita preferred microhabitats with smaller water depth, while in the regulated Cetina River catchment, this species favoured microhabitats with greater water depth, which could be related to its broad ecological tolerance (Buffagni et al., 2009; 2017).

In both catchments, mayfly assemblages shifted from being grazer/scraper-dominated in all microhabitats in the springs and upstream sites to detritivore-dominated downstream. Due to the morphology of the studied karst hydro-systems, which are mainly characterized by high water velocity and presence of coarse sized sediment and aquatic vegetation with trapped organic matter and overgrown with periphyton (e.g. Bonacci, 1987; Plenković-Moraj et al., 2002), the highest proportion of grazers (e.g. Rh. braaschi, E. assimilis) and gatherers (e.g. C. macrura, P. submarginata) (Buffagni et al., 2009; 2017) is not surprising. In the Cetina River catchment and in the Bijela Rijeka River in the Plitvice Lakes catchment, riparian vegetation forms an open canopy. It enables algal growth that benefits grazers, and macrophyte growth that benefits gatherers due to the accumulation of organic particles on the vegetation (Miliša et al., 2006). Active filter feeders (e.g. E. danica, E. lineata) appeared in microhabitats located the middle reaches of the Cetina River (see in Vilenica et al., 2016b) and lower reaches of the Crna Rijeka River, especially on silty substrates, where slower water velocity caused an accumulation of fine sediment and organic matter (Vilenica et al., 2016b; 2017). In the Plitvice Lakes catchment, tufa barriers - natural lake outlets, had the highest proportion of active filter feeders in the majority of microhabitats due to the accumulation of organic particles on barrier substrates (Obelić et al., 2005).

In conclusion, as previously recorded for other aquatic insects (e.g. Šemnički et al., 2012), the mayfly assemblage composition and structure in both studied river systems are influenced by microhabitat characteristics (i.e. water velocity, water depth and substrate type) only to a certain degree, and are more reliant on the availability of different food resources (e.g. Plenković-Moraj et al., 2002; Miliša et al., 2006) and the 

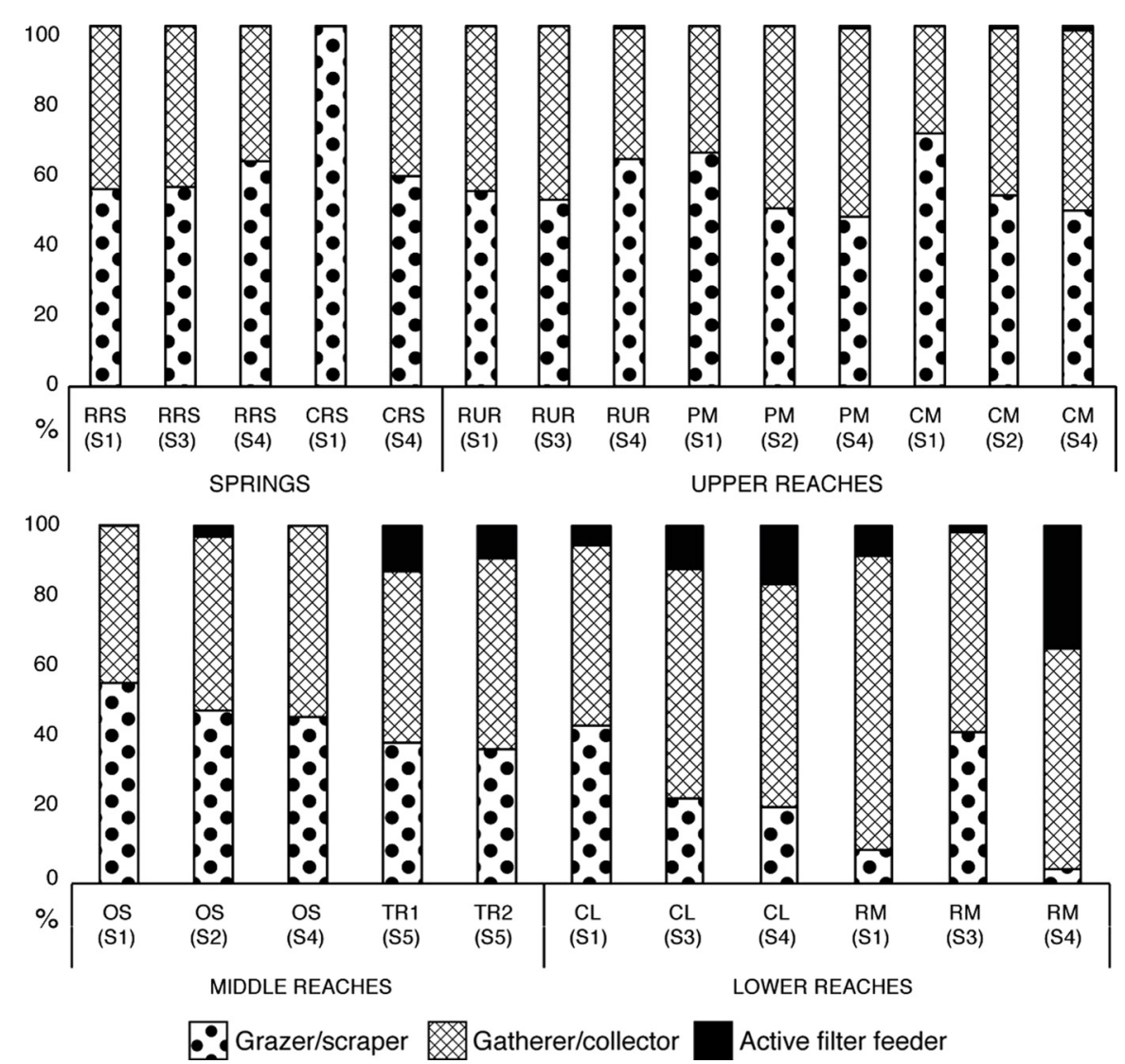

Fig. 5. Percentage abundance of diverse functional feeding groups of mayfly assemblages and their distribution in various habitats and microhabitats in the Cetina River catchment. Legend: S1 - boulders; S2 - angiosperms; S3 - mosses; S4 - sand; S5 - silt. For abbreviations of study site names see Fig. 1.

physical and chemical water properties (Vilenica et al., 2014; 2016a, b; 2017). These are related to the position within the barrage-lake system in the Plitvice Lakes catchment and to the longitudinal distribution in the Cetina River catchment. Even though still greatly under-studied, the Dinaric Karst area represents one of the global biodiversity hotspots (Bãnãrescu, 2004; Griffiths et al., 2004; Ivković and Plant, 2015), which is also highly threatened due to numerous anthropogenic pressures (Štambuk-Giljanović, 2001; Obelić et al., 2005; Chatzinikolaou et al., 2006; Tierno de Figueroa et al., 2013). Since mayflies are widely used as bioindicators of freshwater ecosystems (Landa and Soldán, 1991), data on mayfly ecology, i.e. microhabitat preferences presented here, represent the necessary background for further research and conservation practices in karst streams and rivers.

Acknowledgements. This study was conducted as a part of the following projects: "Arthropod biological diversity in protected karstic habitats in Croatia" (No. 119-1193080-1206) headed by Prof. Dr. Mladen Kučinić and "Invertebrate taxonomy, ecology and biogeography of Croatian aquatic ecotones" (No. 119-1193080-3076) headed by Prof. Dr. Mladen Kerovec. We would like to thank them for their support. We would like to thank our colleagues from the University of Zagreb, Faculty of Science, Department of Biology for their field sampling assistance and sampling sorting in the laboratory. Many thanks to Dr. Ana Previšić, Dr.
Helen Barber James, Dr. Jasna Lajtner and Dr. Rachel Stubbington for their comments and advice, and Miran Katar for help with the artwork. Finally, we would like to thank the reviewers for their useful suggestions that markedly improved the manuscript.

\section{References}

Álvarez-Troncoso R, Benetti Cesar J, Sarr AB, Garrido J. 2017. The microhabitat preferences of Trichoptera in rivers in north-western Spain. Mar Freshwater Res 68: 1686-1694. https://doi.org/ 10.1071/MF16246

Arimoro FO, Muller WJ. 2010. Mayfly (Insecta: Ephemeroptera) community structure as an indicator of the ecological status of a stream in the Niger Delta area of Nigeria. Environ Monit Assess 166: 581-594.

Bae WJ, McCafferty WP. 1994. Microhabitat of Anthopotamus verticis (Ephemeroptera: Potamanthidae). Hydrobiologia 288: 65-78.

Bãnãrescu PM. 2004. Distribution pattern of the aquatic fauna of the Balkan Peninsula. In Griffith H, Kryštufek B, Reed JM, eds. Balkan Biodiversity Pattern and Process in the European Hotspot, Dordrecht: Kluwer Academic Publishers, pp. 203-219.

Baptista DF, Buss DF, Dorvillé LFM, Nessimian JL. 2001. Diversity and habitat preference of aquatic insects along the longitudinal gradient of the Macaé River basin, Rio de Janeiro, Brazil. Rev Bras Biol 61: 249-258. 
Bauernfeind E, Moog O. 2000. Mayflies (Insecta: Ephemeroptera) and the assessment of ecological integrity: a methodological approach. Hydrobiologia 423: 71-83.

Bauernfeind E, Soldán T. 2012. The mayflies of Europe (Ephemeroptera), Denmark: Apollo Books, Ollerup, 781 p.

Baxter RM. 1977. Environmental effects of dams and impoundments. Annu Rev Ecol Evol Syst 8: 255-83.

Bonacci O. 1987. Karst Hydrology, With Special Reference to the Dinaric Karst. Berlin: Springer Verlag, 184 p.

Bonacci O, Pipan T, Culver D. 2008. A framework for karst ecohydrology. Environ Geol 56: 891-900.

Brittain JE, Sartori M. 2003. Ephemeroptera (Mayflies). In Resh VH, Cardé RT, eds. Encylopedia of Insects, Amsterdam: Academic Press, pp. 373-380.

Buffagni A, Desio F. 1994. Le specie del genere Baetis Leach (Ephemeroptera: Baetidae) nell' Italia settentrionale: sintesi ecologica. Atti Cong Naz Ital Entomol 17: 413-416.

Buffagni A, Crosa G, Marchetti R. 1995. Size-related shift in the physical habitat in two mayfly species (Ephemeroptera). Freshw Biol 34: 297-302.

Buffagni A, Cazzola M, López-Rodríguez MJ, Alba-Tercedor J, Armanini DG. 2009. Volume 3-Ephemeroptera. In Schmidt-Kloiber A, Hering D, eds. Distribution and Ecological Preferences of European Freshwater Organisms, Sofia-Moscow: Pensoft Publishers, pp. 1-254.

Buffagni A, Armanini DG, Cazzola M, et al. 2017. Dataset "Ephemeroptera". www.freshwaterecology.info - the taxa and autecology database for freshwater organisms, version 7.0 (accessed on 16.05.2017).

Chatzinikolaou Y, Dakos V, Lazaridou M. 2006. Longitudinal impacts of anthropogenic pressures on benthic macroinvertebrate assemblages in a large transboundary Mediterranean river during the low flow period. Acta Hydrochim Hydrobiol 34: 453-463.

Ciborowski JJH. 1983. Influence of current velocity, density, and detritus on drift of two mayfly species (Ephemeroptera). Can J Zool 61: 119-125.

Ciborowski JJH, Clifford HF. 1983. Life histories, microdistribution and drift of two mayfly (Ephemeroptera) species in the Pembina River, Alberta, Canada. Holarct Ecol 6: 3-10.

Clarke KR, Gorley RN. 2006. PRIMER V6: User Manual/Tutorial. Primer-E, Plymouth.

Collier KJ. 1994. Influence of nymphal size, sex and morphotype on microdistribution of Deleatidium (Ephemeroptera: Leptophlebiidae) in a New Zealand River. Freshw Biol 31: 35-42.

Corkum LD, Pointing PJ, Ciborowski JJH. 1977. The influence of current velocity and substrate on the distribution and drift of two species of mayflies (Ephemeroptera). Can J Zool 55: 1970-1977.

Dedieu N, Rhone M, Vigouroux R, Céréghino R. 2015. Assessing the impact of gold mining in headwater streams of Eastern Amazonia using Ephemeroptera assemblages and biological traits. Ecol Indic 52: 332-340. http://dx.doi.org/10.1016/j.ecolind.2014.12.012.

Dell Inc. 2016. Dell Statistica (data analysis software system), version 13. software.dell.com.

Dinakaran S, Anbalagan S. 2006. Seasonal variation and substrate selection of aquatic insects in a small stream in Sirumalai hills of southern Western Ghats. J Aquat Biol 21: 37-42.

Dufrêne M, Legendre P. 1997. Species assemblages and indicator species: the need for a flexible asymmetrical approach. Ecol Monogr 67: 345-366.

European Environment Agency. 2008. Biogeographical regions in Europe. https://www.eea.europa.eu/publications/re port_2002_0524_154909/biogeographical-regions-in-europe (Assessed on 11.10.2017)

Freyhof J. 2012. Threatened freshwater fishes and molluscs of the Balkan, potential impact of hydropower projects, Unpublished report, ECA Watch Austria \& EuroNatur, 82 p.
Giller PS, Malmqvist B. 1998. The Biology of Streams and Rivers, New York: Oxford University Press, 296 p.

Gligora Udovič M, Cvetkoska A, Žutinić P, et al. 2017. Defining centric diatoms of most relevant phytoplankton functional groups in deep karst lakes. Hydrobiologia 788: 169-191. DOI: 10.1007/ s10750-016-2996-z.

Gordon NB, McMahon TA, Finlayson BL. 1992. Stream Hydrology: an introduction for ecologists, Chichester: Wiley, 429 p.

Graf WL. 2005. Geomorphology and American dams: the scientific, social and economic context. Geomorphology 71: 3-26.

Griffiths HI, Kryštufek B, Reed JM. 2004. Balkan Biodiversity, Pattern and Process in the European Hotspot, Dordrecht: Kluwer Academic Publishers.

Hawkins CP. 1985. Substrate associations and longitudinal distributions in species of Ephemerellidae (Ephemeroptera: Insecta) from western Oregon. Freshw Invertebr Biol 4: 181-188.

Holomuzki JR, Messier SH. 1993. Habitat selection by the stream mayfly Paraleptophlebia guttata.J N Am Benthol Soc 12: 126-135.

Ivković M, Plant A. 2015. Aquatic insects in the Dinarides: identifying hotspots of endemism and species richness shaped by geological and hydrological history using Empididae (Diptera). Insect Conserv Diver. http://dx.doi.org/10.1111/icad.12113.

IUCN. 1979. IUCN Review. World Heritage Nomination. Lake Plitvice National Park.

Lamp WO, Britt NW. 1981. Resource partitioning by two species of stream mayflies (Ephemeroptera: Heptageniidae). Great Lakes Entomol 14: 151-157.

Lampert W, Sommer U. 1997. Limnoecology: the ecology of lakes and streams, Oxford: Oxford University Press, $323 \mathrm{p}$.

Landa V, Soldán T. 1991. The possibility of mayfly faunistics to indicate environmental changes of large areas. In Tercedor JA, Ortega JS, eds. Overview and Strategies of Ephemeroptera and Plecoptera, Gainesville, Florida: Sandhill-Crane Press, pp. 559565.

Leitner P, Hauer C, Ofenböck T, Pletterbauer F, Schmidt-Kloiber A, Graf W. 2015. Fine sediment deposition affects biodiversity and density of benthic macroinvertebrates: A case study in the freshwater pearl mussel river Waldaist (Upper Austria). Limnologica 50: 54-57.

McCune B, Mefford MJ. 2006. PC-ORD. Multivariate Analysis of Ecological Data, Version 5.0 for Windows.

Mihevc A, Zupan-Hajna N, Prelovšek M. 2010. Case study from the Dinaric karst of Slovenia. In Mihevc A, Prelovšek M, Zupan-Hajna N, eds. Introduction to the Dinaric Karst, Postojna: Karst Research Institute, pp. 49-66.

Milesi SV, Doledec S, Melo AS. 2016. Substrate heterogeneity influences the trait composition of stream insect communities: an experimental in situ study. Freshw Sci 35: 1321-1329. http://dx. doi.org/10.1086/688706

Miliša M, Habdija I, Primc-Habdija B, Radanović I, Matoničkin Kepčija R. 2006. The role of flow velocity in the vertical distribution of particulate organic matter on moss-covered travertine barriers of the Plitvice Lakes (Croatia). Hydrobiologia 553: 231-243.

Minshall GW. 1984. Aquatic Insect - substratum relationship. In Resh VH, Rosenberg DM, eds. The Ecology of Aquatic Insects, New York: Praeger Scientific, pp. 358-400.

Monaghan MT, Robinson CT, Spaak P, Ward JV. 2005. Macroinvertebrate diversity in fragmented Alpine streams: implications for freshwater conservation. Aquat Sci 67: 454-464.

Moog O. 2002. Fauna Aquatica Austriaca, Edition 2002, Wassserwirtschaftskataster, Bundesministerium für Land und Forstwirtschaft, Umwelt und Wasserwirtschaft, Vienna. 
Obelić B, Horvatinčić N, Barešić J, Briansó Babinka S, Suckow A. 2005. Anthropogenic pollution in karst lake sediments (Croatia). In Özkul M, Yaĝiz S, Jones B, eds. Proceedings of 1st International Symposium on Travertine, Denizli, Turkey, pp. 179-186.

Plenković-Moraj A, Horvatinčić N, Primc-Habdija B. 2002. Periphyton and its role in tufa deposition in karstic waters (Plitvice Lakes, Croatia). Biologia 57: 423-432.

Popijač A, Sivec I. 2009. Diversity and distribution of stoneflies in the area of Plitvice Lakes National Park and along the Mediterranean River Cetina (Croatia). Aquat Insect 31: 731-742. DOI: 10.1080/ 01650420902745521.

Previšić A, Kerovec M, Kučinić M. 2007. Emergence and composition of Trichoptera from karst habitats, Plitvice Lakes Region, Croatia. Int Rev Hydrobiol 92: 61-83. DOI: 10.1002/ iroh.200510921.

Previšić A, Walton C, Kučinić M, Mitrikeski PT, Kerovec M. 2009. Pleistocene divergence of Dinaric Drusus endemics (Trichoptera, Limnephilidae) in multiple microrefugia within the Balkan Peninsula. Mol Ecol 18: 634-647.

Previšić A, Schnitzler J, Kučinić M, et al. 2014. Microscale vicariance and diversification of Western Balkan caddisflies linked to karstification. Freshw Sci 33: 250-262.

Ramette A. 2007. Multivariate analyses in microbial ecology. FEMS Microbiol Ecol 62: 142-160.

Rounick JS, Winterbourn MJ. 1983. Leaf processing in two contrasting beech forest streams: effects of physical and biotic factors on litter breakdown. Arch Hydrobiol 96: 448-474.

Sarr AB, Benetti CJ, Fernández-Díaz M, Garrido J. 2013. The microhabitat preferences of water beetles in four rivers in Ourense province, northwest Spain. Limnetica, 32: 1-10.

Savić A, Randjelović V, Krpo-Ćetković J. 2010. Seasonal variability in community structure and habitat Selection of mayflies (Ephemeroptera) in the Nišava River (Serbia). Biotechnol Biotechnol Equip 24: 639-645. DOI: 10.1080/ 13102818.2010.10817913.

Schmedtje U, Colling M. 1996. Ökologische Typisierung der aquatischen Makrofauna. Informationsberichte des Bayerischen Landesamtes für Wasserwirtschaft 4: 1-543.

Schmidt-Kloiber A, Hering D. 2015. www.freshwaterecology.info an online tool that unifies, standardises and codifies more than 20,000 European freshwater organisms and their ecological preferences. Ecol Indic 53: 271-282. DOI: 10.1016/j.eco lind.2015.02.007. (accessed on 30.09.2017).

Schwarz U. 2012. Balkan Rivers-The Blue Heart of Europe, Hydromorphological Status and Dam Projects. Report, Vienna, Austria, $151 \mathrm{p}$.

Sroka P, Klecka J, Boukal DS. 2016. Spatial heterogeneity and habitat permanence affect community assembly but not phenology of mayflies (Ephemeroptera) in sandpit pools. Zoosymposia 11: 205218. http://dx.doi.org/10.11646/zoosymposia.11.1.20.

Stahler A. 1952. Hypsometric (area altitude) analysis of erosional topology. Geol Soc Am Bull 63: 1117-1142.

Stilinović B, Božičević S. 1998. The Plitvice Lakes - a natural phenomenon in the middle of the Dinaric karst in Croatia. Eur Water Manage 5: 15-24.
Subramanian KA, Sivaramakrishnan KG. 2005. Habitat and microhabitat distribution of stream communities of the Western Ghats. Curr Sci 89: 976-987.

Šegota T, Filipčić A. 2003. Köppenova podjela klima i hrvatsko nazivlje. Geoadria 8: 17-23. (In Croatian).

Šemnički P, Previšić A, Ivković M, Čmrlec K, Mihaljević Z. 2012. Tufa barriers from a caddisfly's point of view: Streams or lake outlets? Internat Rev Hydrobiol 97: 465-484.

Špoljar M, Primc-Habdija B, Habdija I. 2007. Transport of seston in the karstic hydrosystem of the Plitvice Lakes (Croatia). Hydrobiologia 579: 199-209. DOI: 10.1007/s10750-006-0409-4.

Štambuk-Giljanović N. 2001. The quality of water in Buško Blato Reservoir. Environ Monit Assess 71: 279-296.

Tierno de Figueroa JM, López-Rodríguez MJ, Fenoglio S, SánchezCastillo P, Fochetti R. 2013. Freshwater biodiversity in the rivers of the Mediterranean Basin. Hydrobiologia 719: 137-186.

UNEP/MAP/PAP. 2000. River Cetina Watershed and the Adjacent Coastal Area: Environmental and Socio-economic Profile. Priority Actions Programme, Split.

Urbanič G, Toman MJ, Krušnik C. 2005. Microhabitat type selection of caddisfly larvae (Insecta: Trichoptera) in a shallow lowland stream. Hydrobiologia 541: 1-12. DOI:10.1007/S10750-0044314-4.

Vilenica M, Gattolliat J-L., Ivković M, et al. 2014. The mayfly fauna (Insecta, Ephemeroptera) of the Plitvice Lakes National Park, Croatia. Nat Croat 23: 349-363.

Vilenica M, Gattolliat J-L, Mihaljević Z, Sartori M. 2015. Croatian mayflies (Insecta, Ephemeroptera): species diversity and distribution patterns. ZooKeys 523: 99-127. DOI: 10.3897/zookeys.523.6100.

Vilenica M, Previšić A, Kučinić M, Gattolliat J-L., Sartori M, Mihaljević Z. 2016a. Distribution and autecology of mayflies (Insecta, Ephemeroptera) in a Mediterranean river in the Western Balkans. Entomol News 126: 19-35.

Vilenica M, Previšić A, Ivković M, et al. 2016b. Mayfly (Insecta: Ephemeroptera) assemblages of a regulated perennial Mediterranean river system in the Western Balkans. Biologia 71: 1038-1048. DOI: 10.1515/biolog-2016-0121.

Vilenica M, Brigić A, Kerovec M, Gottstein S, Ternjej I. 2016c. Spatial distribution and seasonal changes of mayflies (Insecta, Ephemeroptera) in a Western Balkan peat bog. ZooKeys 637: 135149. https://doi.org/10.3897/zookeys.637.10359.

Vilenica M, Mičetić Stanković V, Sartori M, Kučinić M, Mihaljević Z. 2017. Environmental factors affecting mayfly assemblages in tufadepositing habitats of the Dinaric Karst. Knowl Manag Aquat Ecosyst 418. DOI: $10.1051 / \mathrm{kmae} / 2017005$.

Ward JV, Stanford JA. 1979. The Ecology of Regulated Streams, Springer, $391 \mathrm{p}$.

Webster JR, Benfield EF, Golladay SW, et al. 1987. Experimental studies of physical factors affecting seston transport in streams. Limnol Oceanogr 32: 848-863.

Wentworth CK. 1922. A scale of grade and class terms for clastic sediments. J Geol 30: 377-392.

Cite this article as: Vilenica M, Brigić A, Sartori M, Mihaljević Z. 2018. Microhabitat selection and distribution of functional feeding groups of mayfly larvae (Ephemeroptera) in lotic karst habitats. Knowl. Manag. Aquat. Ecosyst., 419, 17. 